\title{
Evaluation of Job Stress and Morale at a Federal Law Enforcement Agency's District
}

Facilities

\section{Douglas M. Wiegand, PhD Stefanie M. Brown, MA}

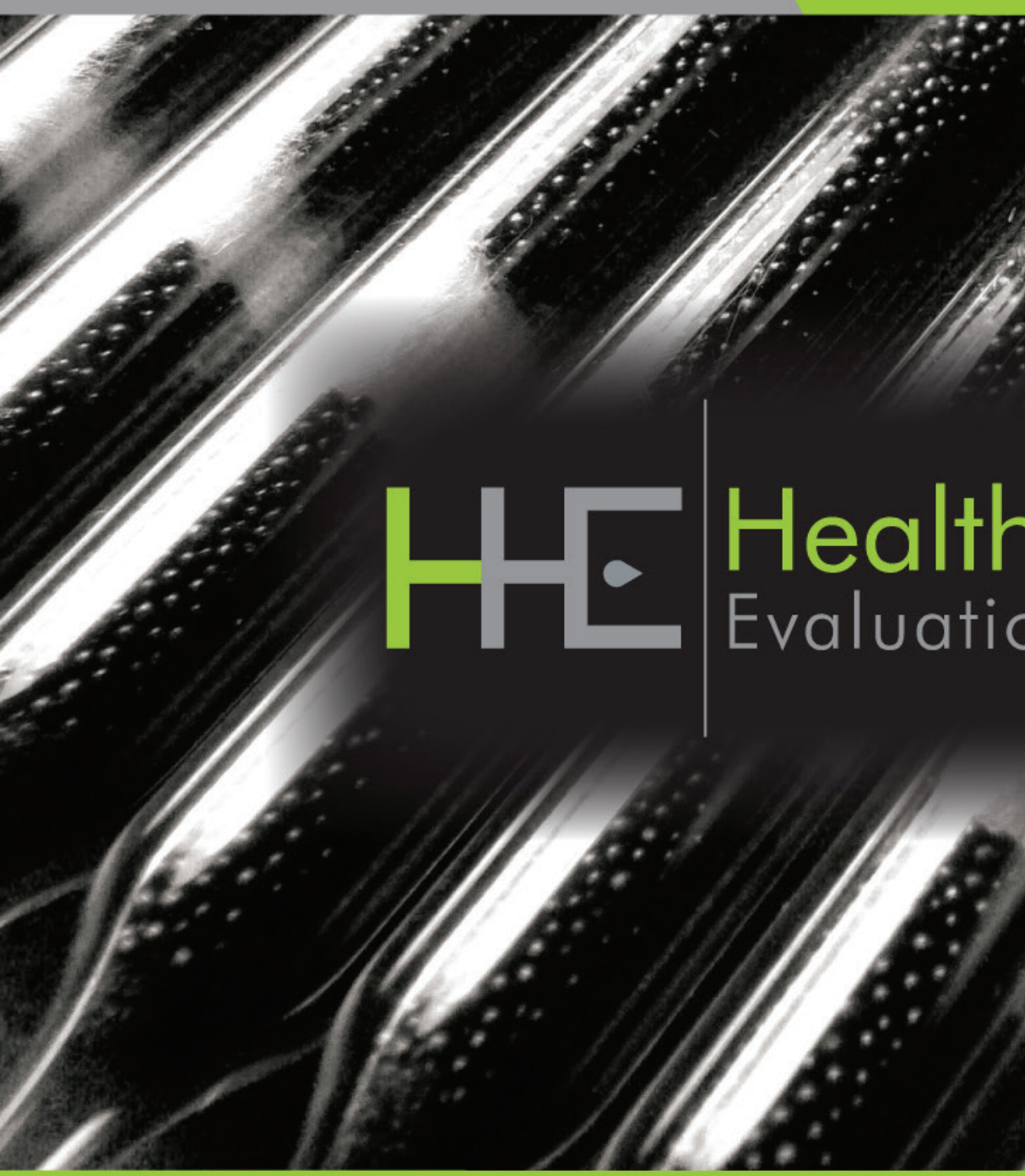

Report No. 2012-0160-3212 June 2014

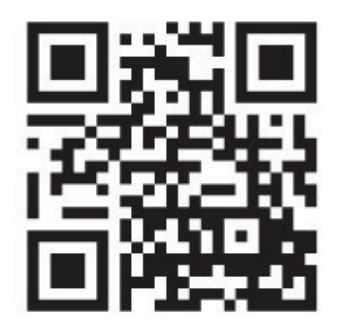

U.S. Department of Health and Human Services Centers for Disease Control and Prevention National Institute for Occupational Safety and Health

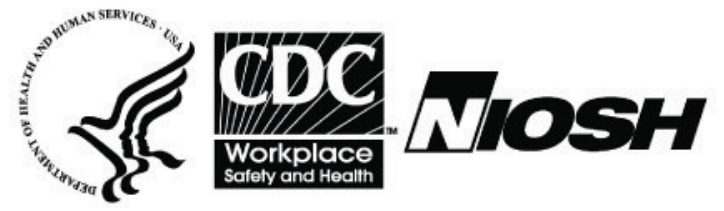




\section{Contents}

Highlights.................................................. i

Introduction ............................................ 1

Background......................................... 1

Methods .............................................. 1

Results ............................................... 3

Discussion.............................................. 8

Conclusions........................................ 10

Recommendations.............................. 10

References................................................12

Acknowledgements............................ 15

The employer is required to post a copy of this report for 30 days at or near the workplace(s) of affected employees. The employer must take steps to ensure that the posted report is not altered, defaced, or covered by other material.

The cover photo is a close-up image of sorbent tubes, which are used by the HHE Program to measure airborne exposures. This photo is an artistic representation that may not be related to this Health Hazard Evaluation. Photo by NIOSH. 


\section{Highlights of this Evaluation}

The Health Hazard Evaluation Program received a request from the American Federation of Government Employees, Local 2718. The union was concerned about job stress and morale among federal law enforcement employees at their district facilities in Illinois.

\section{What We Did}

- We visited the federal law enforcement agency's district facilities in November 2012.

- We surveyed employees about job stress, morale, work organization, organizational commitment, job satisfaction, mental health symptoms, and use of sick leave.

- We talked to randomly selected employees about work-related health concerns, communication, and morale.

\section{What We Found}

- Employees reported moderate job stress and low morale. Employees reported high workloads, unfair treatment, and dissatisfaction with supervisors as contributing to job stress and low morale.

- Employee fatigue and symptoms of depression and anger were common.

- Nearly half of the interviewed employees reported a work-related health concern. The

We evaluated job stress, morale, and mental health symptoms at a federal law enforcement agency's district facilities in Illinois. Employees reported moderate job stress and low morale at work. Fatigue and symptoms of depression and anger were common. We made administrative recommendations to better manage employees' workload and job stress and improve employee morale at work. most common concerns were the impact of job stress on their health, catching a cold or virus from contact with ill detainees, and trouble sleeping.

- Employees want to receive important information (e.g., changes in policies/procedures) jointly through meetings and email.

- Most employees reported that the facility's management was approachable. However, they did not believe their concerns or complaints would be addressed.

\section{What the Employer Can Do}

- Talk to employees about whether workload could be better managed and if so, how.

- Work with the agency's human resources department to improve transparency in hiring and promotional practices.

- Communicate and enforce policies for holding employees accountable for poor performance. 
- Consider working with the Office of Personnel Management to explore why some employees reported dissatisfaction with their supervisors.

- Improve communication about the response to employees' concerns.

\section{What Employees Can Do}

- Get emergency help immediately if you are thinking about harming yourself or someone else.

- Seek counseling if you are depressed, angry, or have other mental health problems. Get help from a licensed clinical psychologist or psychiatrist.

- Wash your hands thoroughly after close contact with ill detainees and other people at work.

- Get the seasonal influenza vaccine every year. 


\section{Introduction}

The Health Hazard Evaluation Program received a request from the American Federation of Government Employees, Local 2718 regarding employees of a federal law enforcement agency's district facilities in Illinois. The request concerned perceived low morale, job stress, and communication problems between employees and the employer. We visited the agency's district office and a service and staging facility in November 2012.

\section{Background}

\section{Federal Law Enforcement Agency}

The district facilities we evaluated were part of a federal agency within the Department of Homeland Security, which was charged with protecting national security by enforcing immigration and customs laws.

The district office served as an immigration court and processing center for adult immigrant detainees who entered the agency's custody. Approximately 100 immigrant detainees were processed at this facility every week.

The service and staging facility served as a processing center for approximately 300 adult immigrant detainees who entered the agency's custody every week. This facility received transfer detainees from many sources, including local jails, the U.S. Marshals Service, and the agency's other detention facilities across the United States. The facility also served as the last stop for immigrants without necessary documentation before being deported.

Thirty employees were recently promoted within the district facilities. This shift in the workforce left vacancies that had not been filled. The employer encouraged employees to cross-train, volunteer for additional duties, and become enrolled in the mentoring program to improve chances for promotion.

\section{Methods}

The purpose of our evaluation was to: (1) assess employees' level of job stress and associated stressors, (2) assess employees' perception of morale at work, (3) assess employees' organizational commitment and job satisfaction, (4) screen employees for general mental health symptoms, (5) assess use of sick leave, and (6) provide recommendations as needed to mitigate job stress and improve employees' morale at work.

\section{Employee Surveys}

We distributed a self-administered, anonymous survey along with instructions and information regarding participant confidentiality to all of the 137 employees that were present at the district office and the staging and service facility during our visit. Participants were asked to seal their completed survey in an envelope and return it directly to us. The survey focused on job stress, perceived morale, organizational commitment, job satisfaction, mental health symptoms, and use of sick leave. 


\section{Job Stress}

We asked participants to rate their level of job stress with the following survey item: "During the past week, including today, how would you rate your current job stress level on a scale from 0 (as low as it can be) to 10 (as high as it can be)?" Responses of 0-3 indicated low job stress, 4-6 indicated moderate job stress, and scores of 7 or greater indicated high job stress [Clark et al. 2011].

We asked participants to rate the level of stress they associated with 25 items describing stressors common to law enforcement officers [Spielberger et al. 1981; McCreary and Thompson 2006] using a scale from 1 (no stress at all) to 7 (a lot of stress).

\section{Perceived Morale at Work}

We asked participants to rate morale at work with the following survey item: "Please rate your perception of morale at work on a scale from 0 (as low as it can be) to 10 (as high as can be)." Responses of 0-3 indicated low morale, 4-6 indicated moderate morale, and scores of 7 or greater indicated high morale [Clark et al. 2011].

\section{Organizational Commitment and Job Satisfaction}

We asked participants to rate their level of agreement with 10 statements describing organizational commitment (i.e., an individual's identification with and involvement in an organization) [Mowday et al. 1979] and job satisfaction [Hurrell and McLaney 1988] on a scale from 1 (strongly disagree) to 7 (strongly agree). We calculated summed composite scores for organizational commitment and job satisfaction using items which displayed internal consistency with a Chronbach's alpha of greater than 0.70 . These composite scores were used in statistical analyses to see if these factors were associated with job stress and morale.

\section{Mental Health Symptoms}

We asked participants to indicate how often they had symptoms of depression, anxiety, and anger in the past 30 days, based on a scale from 1 (none of the time) to 5 (all of the time). We calculated a total score for these symptoms. We used the symptom score in a statistical analysis to see if it was associated with reported job stress and morale. We also asked about use of sick leave.

\section{Employee Suggestions for Improving Working Conditions}

Employees were asked an open-ended question regarding suggestions for improving their working conditions.

\section{Employee Interviews}

We interviewed a random selection of employees $(\mathrm{N}=57$; chosen from an employee roster using a random number generator). The interview focused on work-related health concerns, communication in the workplace, and morale. Questions included yes/no and open-ended response options. 


\section{Results}

\section{Employee Survey}

Of 137 employee surveys, 72 (53\%) were returned. (Note: Some respondents did not answer every question in the survey. When the number of respondents was less than 72 , this fact is noted.) Thirty-four $(67 \% ; \mathrm{N}=51)$ respondents were male, and $57(85 \% ; \mathrm{N}=67)$ were aged 26-44. One third of the employees had been with the agency 5 or fewer years, one third had been with the agency for 6-10 years, and one third had been with the agency for more than 10 years. Twenty-four (33\%) respondents were immigration enforcement agents, 19 (26\%) were deportation officers, $12(17 \%)$ were enforcement removal assistants, $9(13 \%)$ had other job titles, and $8(11 \%)$ did not report a job title.

\section{Job Stress}

Employees were asked to rate their level of job stress on a scale from 0 (as low as it can be) to 10 (as high as it can be). The average job stress score was $5.5(\mathrm{~N}=70)$, indicating moderate job stress overall. On the basis of individual scores, 26 (37\%) employees indicated low job stress, $14(20 \%)$ indicated moderate job stress, and 30 (43\%) indicated high job stress.

Participants rated the level of job stress they associated with a list of stressors common to law enforcement officers using a scale from 1 (no stress at all) to 7 (a lot of stress). Table 1 shows items that had the highest average scores above 5. The list is ordered from highest to lowest rated stressors. The stressors with the highest ratings included staff shortages, unequal sharing of work duties, and perceived favoritism.

Table 1. Average ratings of job stressors $(\mathrm{N}=68-70)$ using a scale from 1 (no stress at all) to 7 (a lot of stress)

\begin{tabular}{lc}
\hline Stressor & Average rating \\
\hline Staff shortages & 6.1 \\
Unequal sharing of work responsibilities & 5.7 \\
The feeling that different rules apply to & 5.6 \\
different people (i.e., favoritism) & \\
Bureaucratic "red tape" & 5.5 \\
Inconsistent leadership style & 5.5 \\
Lack of resources & 5.3 \\
Constant changes in policy/legislation & 5.1 \\
\hline
\end{tabular}




\section{Morale at Work}

Employees were asked to rate their perception of morale at work on a scale from 0 (as low as it can be) to 10 (as high as it can be). The average morale score was $2.9(\mathrm{~N}=70)$. On the basis of individual scores, 45 (65\%) employees indicated low morale, $15(22 \%)$ indicated moderate morale, and $9(13 \%)$ indicated high morale. There was no statistically significant association between job stress and morale.

Employees were asked an open-ended question to explain their morale at work score. Forty-nine (68\%) participants responded to this question. Themes reported by five or more employees are listed in Table 2.

Table 2. Employee perceptions of what affects morale at work $(\mathrm{N}=72)$

\begin{tabular}{lc}
\hline Perception & $\begin{array}{c}\text { Number of } \\
\text { participants } \\
\text { reporting (\%) }\end{array}$ \\
\hline No response to item & $23(32)$ \\
Favoritism at work & $14(19)$ \\
Dissatisfaction with supervision & $13(18)$ \\
Understaffed & $8(11)$ \\
Poor relations with coworkers & $8(11)$ \\
Inconsistent disciplinary actions & $8(11)$ \\
Inconsistent promotion practices & $7(10)$ \\
Lack of praise for good work & $6(8)$ \\
Lack of opportunities for promotion & $5(7)$ \\
Effort-reward imbalance & $5(7)$ \\
\hline
\end{tabular}

There is consistency between employees' responses to this question and the ratings of job stressors. Favoritism and being understaffed were common themes. Employees reported that work was reassigned when the workforce had decreased due to promotions, and that supervisors were not consistent or fair in terms of assigning workloads evenly among the employees.

\section{Organizational Commitment and Job Satisfaction}

Employees were asked to rate their level of agreement with statements about organizational commitment and job satisfaction on a scale from 1 (strongly disagree) to 7 (strongly agree). Average scores for each item are shown in Table 3. Employees reported that they are willing to put in a great deal of effort at work, but overall job satisfaction and the desire to maintain employment with the agency were low. Satisfaction with workload was low, and employees reported that they found it difficult to agree with the agency's policies relating to its employees. 
Table 3. Average responses to organizational commitment and job satisfaction survey items $(\mathrm{N}=69-71)$ using a scale from 1 (strongly disagree) to 7 (strongly agree)

\begin{tabular}{lc}
\hline Survey item & Average score \\
\hline $\begin{array}{l}\text { Organizational commitment } \\
\text { I am willing to put in a great deal of effort beyond that normally }\end{array}$ & 5.2 \\
expected in order to help this organization be successful & \\
I find it difficult to agree with this organization's policies on important & 4.9 \\
matters relating to its employees & 4.7 \\
There is little to be gained by me staying with this organization & 4.1 \\
It would take very little change in my present circumstances to cause & \\
me to leave this organization & 3.7 \\
I am proud to tell others that I am part of this organization & 3.4 \\
I have alternative career options open to me & 3.2 \\
This organization inspires the very best in me in the way of job & \\
performance & \\
\hline Job satisfaction & 4.0 \\
I am satisfied with my salary & 3.6 \\
Overall, I am satisfied with my job & 3.3 \\
\hline
\end{tabular}

Higher job stress was associated with lower levels of organizational commitment. This finding was statistically significant $(P<0.05)$. Higher job stress was also associated with lower total job satisfaction. This finding was statistically significant $(P<0.001)$. Morale was not associated with organizational commitment or job satisfaction. 


\section{Employee Mental Health and Use of Sick Leave}

Employees were asked about the frequency of symptoms of anxiety, depression, and anger on a scale from 1 (none of the time) to 5 (all of the time). We also asked about using alcohol as a coping mechanism. Table 4 shows the average scores of each item and the percentage of employees who responded with a 4 or 5 on the scale. Fatigue was common among employees, as were symptoms of depression (i.e., feeling that everything is an effort, feeling hopeless, feeling worthless) and anger. Use of alcohol to cope was less common.

Table 4. Average scores and percentage of participants scoring $\geq 4$ on a scale from 1 (none of the time) to 5 (all of the time) for frequency of mental health symptoms $(\mathrm{N}=69-71)$

\begin{tabular}{lcc}
\hline During the past 30 days, about how often did you feel... & Average score & $\begin{array}{c}\text { \% of participants } \\
\text { scoring } 4 \text { or } 5\end{array}$ \\
\hline ...fatigued? & 3.1 & 41.5 \\
...angry? & 2.8 & 26.8 \\
...that everything was an effort? & 2.7 & 33.3 \\
...less tolerant of others? & 2.6 & 21.1 \\
...nervous? & 2.5 & 18.8 \\
...restless or fidgety? & 2.5 & 18.4 \\
...hopeless? & 2.4 & 26.8 \\
...worthless? & 1.9 & 15.5 \\
...so depressed that nothing could cheer you up? & 1.8 & 11.2 \\
...that drinking alcohol is necessary to help you feel better? & 1.6 & 10.1 \\
\hline
\end{tabular}

A higher level of job stress was associated with increased frequency of mental health symptoms. This finding was statistically significant $(P<0.001)$. Morale was not associated with frequency of mental health symptoms.

Employees were asked how many days of sick leave they had used in the past 6 months. Most employees (71\%) reported that they had taken 6 or fewer sick days. The most common response was 1-3 days. Six (8\%) employees took no sick days, and six (8\%) employees reported taking 15 or more sick days. Use of sick days was not significantly associated with reported job stress, perceived morale, or frequency of mental health symptoms. 


\section{Employee Suggestions for Improving Working Conditions}

Employees were asked an open-ended question about whether they had any suggestions for improving working conditions. Fifty (69\%) employees listed a suggestion. Table 5 includes suggestions made by five or more individuals.

Table 5. Employee suggestions for improving working conditions $(\mathrm{N}=70)$

\begin{tabular}{lc}
\hline Suggestion & $\begin{array}{c}\text { Number of participants } \\
\text { reporting (\%) }\end{array}$ \\
\hline No suggestion made & $22(31)$ \\
Hold employees accountable for their shortcomings or failures & $13(18)$ \\
Hire additional staff to lessen current employees' workload & $13(18)$ \\
Improve management and supervision & $11(15)$ \\
Improve transparency and consistency in promotions & $10(14)$ \\
Eliminate acts of favoritism & $9(13)$ \\
Distribute work evenly & $8(11)$ \\
Improve opportunities for work-life balance & $7(10)$ \\
Provide equal pay for equal work & $7(10)$ \\
Improve training & $6(8)$ \\
Solicit employees' opinions when making policy decisions & $5(7)$ \\
Provide more praise for good work & $5(7)$ \\
\hline
\end{tabular}

\section{Employee Interviews}

We briefly interviewed 57 employees about work-related health concerns and communication at work. These individuals were randomly selected, so it is possible that some of them completed the employee survey, while others may not have. Most interviewed employees were immigration enforcement agents (56\%), followed by deportation officers (26\%), enforcement removal assistants (11\%) and other job titles (7\%). Of the interviewed employees, 42 (74\%) were male. The average age was 38 years. Employees reported an average of 7 years of employment with the agency.

Twenty-seven (47\%) employees reported that they had work-related health concerns, the most common of which were the impact of job stress on health, catching a cold or virus due to close contact with ill detainees, and insomnia/fatigue. When asked whether the employer had discussed potential exposures and stressors associated with the job, 12 (21\%) responded "yes."

We asked questions about how employees received important information, such as changes in policies or procedures, and what their preferred method of receiving this information was. Most employees (79\%) reported that they preferred to receive important information from the local management or their front line supervisor (as opposed to the union, agency management, or from peers), and the preferred method for receiving such information was in face-to-face meetings (45\%) or the combination of an initial email with a follow-up meeting to discuss $(34 \%)$. 
Forty-nine (86\%) employees responded "yes" when asked "Do you think there is a communication issue between management and employees in this workplace?" Two general themes emerged when employees were asked to elaborate on their response to this question $(\mathrm{N}=42)$. The most frequently reported theme $(50 \%)$ was poor relations and poor communication between union representatives and management. The other most frequently reported theme (31\%) was a lack of employee input into decision making, although specifics regarding the nature of these decisions were not discussed.

Most employees (79\%) reported that their management was approachable when it came to reporting health concerns within the workplace. Forty-six employees commented further, and of these, $14(30 \%)$ indicated that they believed their concerns would not be addressed if brought to management's attention.

The interviews with employees supported the survey findings with regard to morale being low in the workplace. The most frequently reported reasons for low morale included perceived favoritism in terms of promotions, unequal distribution of workload, and feeling that some employees were not held accountable for poor performance.

Approximately one third of interviewed employees reported that they believed management was taking steps to improve employee morale. Management reported that recent attempts were made to improve morale and team building, such as having guest motivational speakers, organizing social events after hours, and promoting employees.

\section{Discussion}

The purpose of this health hazard evaluation was to assess employees' levels of job stress, morale, organizational commitment, job satisfaction, mental health symptoms, work-related health concerns, and perceptions of communication.

Research in job stress associated with law enforcement typically groups stressors into two types. Operational stressors are aspects of police work that are inherent in the occupation (e.g., overtime, exposure to violence, shiftwork), while organizational stressors are related to characteristics of the organization and interactions with the people in them (e.g., bureaucracy, coworker relations, access to resources) [McCreary and Thompson 2006; Shane 2010]. This evaluation focused on organizational stressors due to the concerns reported in the health hazard evaluation request (low morale, apathy, low job satisfaction). Past research indicates that organizational stressors tend to be a greater source of stress than operational stressors in law enforcement. Studies have shown that organizational stressors are associated with lower job satisfaction and frustration [Brown and Campbell 1990; Violanti and Aron 1993; Collins and Gibbs 2003]. The results of this evaluation showed that understaffing, perceived unfairness in workload and treatment of employees, and inconsistent leadership practices were the highest rated organizational stressors. Job stress was associated with low organizational commitment and low job satisfaction.

Some of the organizational stressors explored in this evaluation were areas where employees rated the least satisfaction in the Department of Homeland Security's Federal Employee Viewpoint Survey (82,218 employee respondents; $47 \%$ response rate) [Department of 
Homeland Security 2012]. For example, In the Viewpoint Survey, 41\% agreed that they had sufficient resources, 39\% reported that they were satisfied with communication within the organization, 38\% agreed that arbitrary action and favoritism are not tolerated, $31 \%$ are satisfied with their opportunities for promotion, $25 \%$ agreed that steps are taken to deal with poor performers, and $24 \%$ agreed that promotions are based on merit.

Law enforcement is by nature a very stressful occupation, and stress is associated with reduced physical health, mental health, and well-being in law enforcement employees [Violanti 2011]. Nearly half of the employees who completed interviews reported work-related health concerns, many of which included the impact of job stress on their health.

Symptoms of fatigue, depression, and anger were common at this agency, which is consistent with findings of other law enforcement studies. A recent study of a large police force showed that getting less than 6 hours of sleep in a 24-hour period was more prevalent among police officers than the general public (33\% vs. $8 \%$ ), and that symptoms of depression were more prevalent among police officers than the general public (12\% vs. 6.8\%) [Hartley et al. 2011]. Job stress is associated with fatigue. For example, Kashani et al. [2012] found that individuals experiencing high stress had more daytime sleepiness, greater fatigue, poorer sleep quality, and shorter sleep duration than those who experienced low stress. Fatigue is associated with depression [Slaven et al. 2011] and can also impair job performance [Dawson and Reid 1997]. Law enforcement activities can put officers and the public at risk. It is important that officers are vigilant, clear headed, and able to react quickly if in a potentially dangerous situation. Coping with stress and mental health symptoms and remaining well rested are essential to maintaining well-being and high performance on the job.

Some employees reported frequent feelings of anger and intolerance of others. Chronically high levels of anger and hostility are associated with serious negative health consequences [Friedman 1992]. These negative effects are usually greater for law enforcement officers because their job demands that they do not publicly express their anger [Pate and Spielberger 1979]. Officers must exercise stringent self control and there may be a delay in coping with negative emotions, both of which can be additional stressors.

Employees reported low morale, yet morale was not associated with job stress, organizational commitment, job satisfaction, or mental health symptoms. We explored this inconsistency by comparing employees' morale scores with their open-ended explanations of their scores. We found four discrepancies where participants scored morale as high as possible, yet their open-ended responses expressed negative views of the work climate. It is possible these employees misunderstood the morale score item on the survey. When these four morale scores were omitted from analyses, statistically significant associations were found between morale and the other factors. Low morale was associated with high job stress $(P<0.05)$, low organizational commitment $(P<0.001)$, low job satisfaction $(P<0.05)$, and an increased frequency of mental health symptoms $(P<0.05)$.

The interviews suggested that most employees believed there were communication problems in the workplace. Half of those interviewed described poor relationships between the union and management as a communication problem. This is an area that should be explored further 
since union-management cooperation is important in empowering a workforce and leading to greater efficiency and improved public services [Beach and Kaboolian 2005].

Some employees reported that employee input is not considered before decisions are made. Research has shown that employee involvement in decision making and providing input to management is associated with greater job satisfaction, positive perceptions of work, and lower turnover [Kain and Jex 2010].

There were two limitations to this evaluation in terms of generalizability to other populations and the representativeness of our sample within this district. Our evaluation focused on employees in two facilities in Illinois, and our results may not be generalizable to this agency's employees in other districts. Participation in the survey was 53\%, which raises the possibility that our results are not representative of all of the employees who were working in these facilities.

\section{Conclusions}

Employees at these agency facilities reported moderate job stress and low morale. Employee perceptions of understaffing, favoritism, and dissatisfaction with supervision were common themes. Employees reported that communication between the employer and employees was poor, and that they would prefer to have meetings (or meetings plus an email) to discuss important information such as hiring/promotion qualifications or changes in policies/ procedures. Fatigue and symptoms of depression and anger were common. Reducing organizational stressors in the workplace will likely improve employees' levels of job satisfaction, morale, performance, and mental health.

\section{Recommendations}

On the basis of our findings, we recommend the actions listed below. We encourage this agency to use a labor-management health and safety committee or working group to discuss our recommendations and develop an action plan. Those involved in the work can best set priorities and assess the feasibility of our recommendations for the specific situation at these federal law enforcement facilities.

\section{Recommendations for the Employer}

1. Evaluate employee workload distribution to ensure that is it equitable. Engage employees in discussions about whether workload could be better managed and how.

2. Get employee input regarding job demands and how they affect job stress, morale, and job satisfaction.

3. Encourage employees to participate in the annual Federal Employee Viewpoint Survey. The Department of Homeland Security has had low levels of participation for the past several years. The survey data can be used to monitor issues related to morale and job stress within the agency.

4. Ensure supervisors and managers are adequately trained in policies and practices for 
dealing with employee performance issues.

5. Meet with employees to discuss hiring and promotion practices to determine if transparency can be improved, and to address questions/concerns. The agency's human resources department may be helpful in this task. Internal candidates who are not interviewed for or awarded a position/promotion should be debriefed on why their qualifications may not have been the best match for the position and how they may improve their professional development for future job openings.

6. Explore why some employees reported dissatisfaction with their supervisor. The Office of Personnel Management offers services for federal government agencies which may be helpful in completing this task: http://www.opm.gov/services-for-agencies/ assessment-evaluation/.

7. Improve communication with employees, to include regular all-hands meetings where employees are informed of important information and given the opportunity to ask questions or raise points of discussion.

8. Ensure all employees are aware of the services offered by their employee assistance program and how they may seek these services.

9. Ensure employees receive adequate training on the importance of good sleep habits, the hazards associated with fatigue at work, and strategies for managing them. For more information on sleep, see http://www.cdc.gov/sleep/.

10. Identify and isolate ill detainees early, so that employees avoid close contact with those who are sick. Make sure that procedures are in place to handle ill detainees.

11. Encourage proper hand and respiratory hygiene practices, educate workers on influenza signs and symptoms, and promote influenza vaccination among employees. Make employees aware that Federal Occupational Health offers influenza vaccination at no cost to the employee. Explore the feasibility of offering the influenza vaccination to employees at the workplace.

\section{Recommendations for Employees}

1. Get emergency help immediately if you are thinking about harming yourself or someone else.

2. Get counseling from a licensed clinical psychologist or psychiatrist if symptoms of depression, anger, or any other mental health problems are interfering with social, occupational, or other important areas of your life. Consider contacting a representative of your employee assistance program or your primary care physician for assistance with receiving mental health treatment.

3. Wash your hands regularly, particularly after close contact with detainees and other people at work. The Centers for Disease Control and Prevention has information on proper hand washing practices at http://www.cdc.gov/handwashing/.

4. Get the seasonal influenza vaccine every year. 


\section{References}

Beach A, Kaboolian L [2005]. Working better together: a practical guide for union leaders, elected officials and managers to improve public services. [http://www.law.harvard.edu/ programs/lwp/Working\%20Better\%20Together.pdf]. Date accessed: June 2014.

Brown JM, Campbell EA [1990]. Sources of occupational stress in the police. Work Stress 4(4):305-318.

Clark MM, Warren BA, Hagen PT, Johnson BD, Jenkins SM, Werneburg BL, Olsen KD [2011]. Stress level, health behaviors, and quality of life in employees joining a wellness center. Am J Health Promot 26(1):21-25.

Collins PA, Gibbs ACC [2003]. Stress in police officers: a study of the origins, prevalence and severity of stress-related symptoms within a county police force. Occ Med 53(4):256-264.

Dawson D, Reid K [1997]. Fatigue, alcohol and performance impairment. Nature 388(6639):235.

Department of Homeland Security [2012]. 2012 Federal Employee Viewpoint Survey results. [http://www.dhs.gov/sites/default/files/publications/2012_FEVS_DHS_Results.pdf]. Date accessed: June 2014.

Friedman HS [1992]. Hostility, coping, and health. Washington, DC: American Psychological Association.

Hartley TA, Burchfiel CM, Fekedulegn D, Andrew ME, Violanti JM [2011]. Health disparities in police officers: comparisons to the U.S. general population. Int J Emerg Ment Health 13(4):211-220.

Hurrell JJ Jr., McLaney MA [1988]. Exposure to job stress: a new psychometric instrument. Scand J Work Environ Health 14(Supp 1):27-28.

Kain J, Jex S [2010]. Karasek's (1979) job demands-control model: a summary of current issues and recommendations for future research. In: Perrewe PL, Ganster DC, eds. Research in occupational stress and well-being. Vol. 8: New developments in theoretical and conceptual approaches to job stress. Bingley, UK: Emerald Books, pp. 237-268.

Kashani M, Eliasson A, Vernalis M [2012]. Perceived stress correlates with disturbed sleep: a link connecting stress and cardiovascular disease. Stress 15(1):45-51.

McCreary DR, Thompson MM [2006]. Development of two reliable and valid measures of stressors in policing: the Operational and Organizational Police Stress Questionnaires. Int J Stress Manage 13(4):494-518.

Mowday RT, Steers RM, Porter LW [1979]. The measurement of organizational commitment. J Vocat Behav 14(2):224-247.

Pate JM, Spielberger CD [1979, August/September]. Sources of stress in police work. J Fraternal Order Police 60-62. 
Shane JM [2010]. Organizational stressors and police performance. J Crim Just 39(4):807-817.

Slaven JE, Mnatsakanova A, Burchfiel CM, Smith LM, Charles LE, Andrew ME, Gu JK, Ma C, Fededulegn D, Violanti JM [2011]. Association of sleep quality with depression in police officers. Int J Emerg Ment Health 13(4):267-277.

Spielberger CD, Westberry LG, Grier KS, Greenfield G [1981]. The police stress survey: sources of stress in law enforcement (Human Resources Institute Monograph Series Three, No. 6). Tampa, FL: University of South Florida, College of Social and Behavioral Sciences.

Violanti JM, Aron F [1993]. Sources of police stressors, job attitudes, and psychological distress. Psychol Rep 72(3):899-904.

Violanti JM [2011]. Introduction to special issue: stress and health in law enforcement. Int J Emerg Ment Health 13(4):209-210. 
Keywords: North American Industry Classification System 928120 (International Affairs), job stress, morale at work, law enforcement 
The Health Hazard Evaluation Program investigates possible health hazards in the workplace under the authority of the Occupational Safety and Health Act of 1970 (29 U.S.C. § 669(a) (6)). The Health Hazard Evaluation Program also provides, upon request, technical assistance to federal, state, and local agencies to investigate occupational health hazards and to prevent occupational disease or injury. Regulations guiding the Program can be found in Title 42, Code of Federal Regulations, Part 85; Requests for Health Hazard Evaluations (42 CFR Part 85).

\section{Disclaimer}

The recommendations in this report are made on the basis of the findings at the workplace evaluated and may not be applicable to other workplaces.

Mention of any company or product in this report does not constitute endorsement by the National Institute for Occupational Safety and Health (NIOSH).

Citations to Web sites external to NIOSH do not constitute NIOSH endorsement of the sponsoring organizations or their programs or products. NIOSH is not responsible for the content of these Web sites. All Web addresses referenced in this document were accessible as of the publication date.

\section{Acknowledgments}

Desktop Publisher: Shawna Watts

Editor: Ellen Galloway

\section{Availability of Report}

Copies of this report have been sent to the employer, employees, and union at the facility. The state and local health department and the Occupational Safety and Health Administration Regional Office have also received a copy. This report is not copyrighted and may be freely reproduced.

This report is available at http://www.cdc.gov/niosh/hhe/reports/pdfs/2012-0160-3212.pdf.

\section{Recommended citation for this report:}

NIOSH [2014]. Health hazard evaluation report: evaluation of job stress and morale at a federal law enforcement agency's district facilities. By Wiegand DM, Brown SM. Cincinnati, $\mathrm{OH}$ : U.S. Department of Health and Human Services, Centers for Disease Control and Prevention, National Institute for Occupational Safety and Health, NIOSH HHE Report No. 2012-0160-3212. 
Delivering on the Nation's promise:

Safety and health at work for all people through research and prevention

To receive NIOSH documents or more information about occupational safety and health topics, please contact NIOSH:

Telephone: 1-800-CDC-INFO (1-800-232-4636)

TTY: 1-888-232-6348

CDC INFO: www.cdc.gov/info

or visit the NIOSH Web site at www.cdc.gov/niosh

For a monthly update on news at $\mathrm{NIOSH}$, subscribe to

$\mathrm{NIOSH}$ eNews by visiting www.cdc.gov/niosh/eNews. 